\section{DIGITAL COMMONS \\ @ UNIVERSITY OF SOUTH FLORIDA}

\section{Suburban Sustainability}

\title{
Developing a Sustainable Water Supply in the American West: The Case of Rio Rancho, New Mexico
}

\author{
Hubert B. Stroud \\ Arkansas State University-Main Campus, bstroud@astate.edu \\ Mary K. Kilmer \\ Arkansas State University - Main Campus, mary.kilmer@smail.astate.edu
}

Follow this and additional works at: https://digitalcommons.usf.edu/subsust

Part of the Natural Resources and Conservation Commons, Natural Resources Management and Policy Commons, Sustainability Commons, and the Water Resource Management Commons

\section{Recommended Citation}

Stroud, Hubert B. and Kilmer, Mary K. (2016) "Developing a Sustainable Water Supply in the American West: The Case of Rio Rancho, New Mexico," Suburban Sustainability. Vol. 4 : Iss. 1 , Article 1. http://dx.doi.org/10.5038/2164-0866.4.1.1026

Available at: https://digitalcommons.usf.edu/subsust/vol4/iss1/1

This Article is brought to you for free and open access by the Open Access Journals at Digital Commons @ University of South Florida. It has been accepted for inclusion in Suburban Sustainability by an authorized editor of Digital Commons @ University of South Florida. For more information, please contact digitalcommons@usf.edu. 


\section{Introduction}

\section{Background}

Water, a resource that is often taken for granted in the developed world, is becoming an increasingly scarce commodity in many locations. Although more than $70 \%$ of the Earth's surface is covered in water, usable freshwater is extremely limited, comprising just $2.5 \%$ of the total. Most of this freshwater is either stored underground in subterranean aquifers or locked up in polar ice caps and glaciers. Only $1.2 \%$ of all freshwater is available as surface freshwater, contained in rivers, lakes, streams and the atmosphere (Gleick 1993). This limited supply of freshwater is placed under increasing stress as the world population grows and demand for water for agriculture, industry and personal use (e.g., drinking, cooking, cleaning) increases accordingly.

In the most recent report of estimated water use in the United States (Maupin et al. 2014), it was stated that approximately 1158 billion liters (bn L) of freshwater were used per day with 870 bn L being drawn from surface water and 288 bn L being drawn from groundwater. Because availability of water resources can vary drastically, obtaining an adequate potable water supply can be difficult in regions where the population is rapidly expanding and water supplies are dwindling from overuse and pollution. This is certainly the case in the western United States where the demand for water is high and supply has been drastically reduced during the current prolonged period of drought (Lucero and Tarlock 2003).

The problem of limited water supply to cities in the West has been intensified by interstate land sales companies that created large pre-platted subdivisions in various locations across the United States. These ill-conceived land developments create a wide variety of environmental, social and economic problems. The literature is replete with examples addressing these issues (see Stroud 2002; Shultz and Groy 1998; Elliott 1997; Salvensen 1996; Schnidman 1987; Schnidman and Baker 1985; Stroud 1983). While many interstate land sales subdivisions remain virtually uninhabited, some have experienced phenomenal growth; having evolved from land scams to boom towns in relatively short periods of time (see, for example, Allan et al. Oakes 1976; American Society of Planning Officials 1976 and Dodrill 1993).

Some of the largest and most "successful" of these developments are located in the arid southwestern United States (Stroud 1995). An example is Rio Rancho, New Mexico where the population has grown from a mere 1,164 in 1970 to a current population that exceeds 87,000 (Fig. 1). This growth made Rio Rancho the third largest and fastest growing city in New Mexico and one of the fastest growing in the United States. Rio Rancho provides affordable housing, a relatively easy commute to jobs in the Albuquerque metropolitan area, and opportunities for employment at Intel and other industries within the Rio Rancho city limits. For 
these and other reasons, population growth is not expected to slow anytime soon. Current projections estimate that the population of Rio Rancho will reach roughly 160,000 by the year 2040 (Fig. 1).

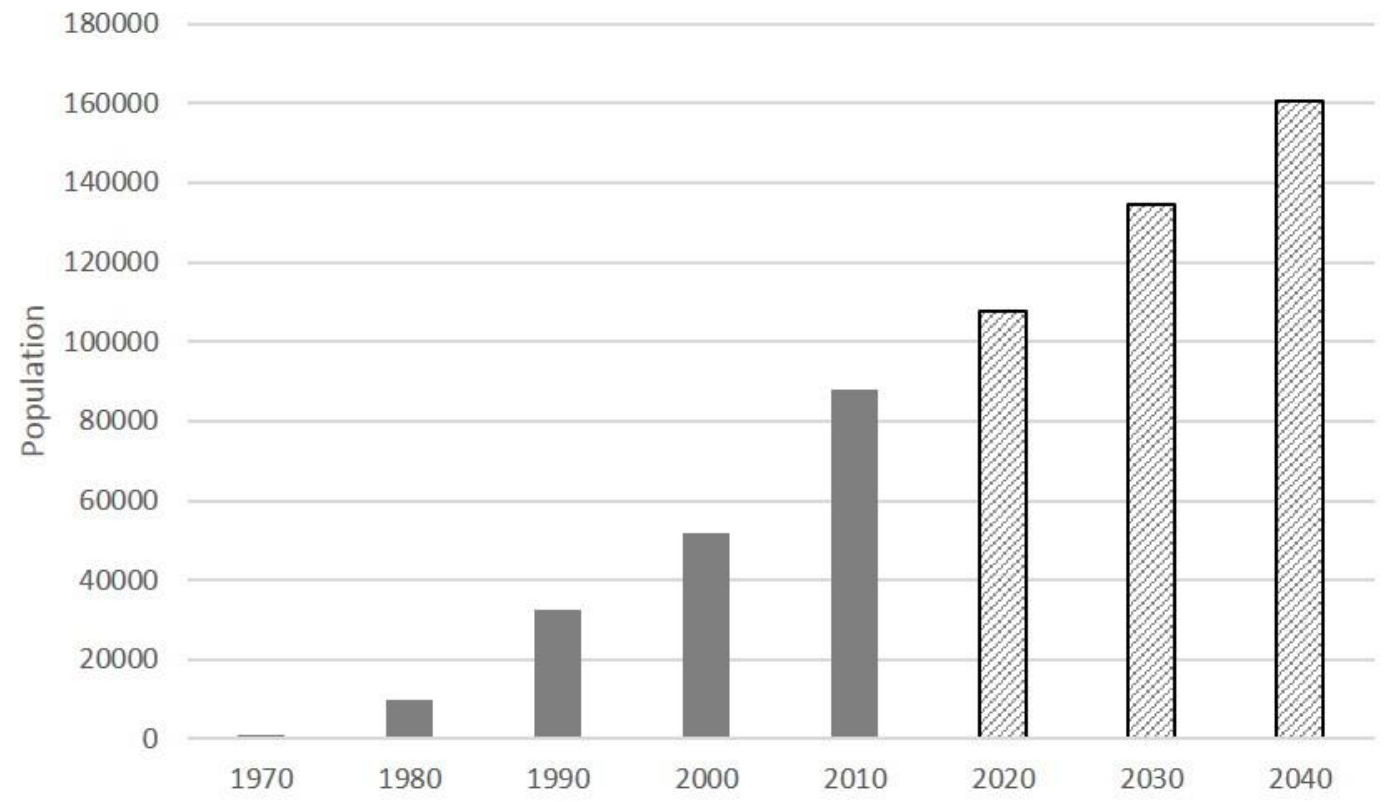

Figure 1. Historic (gray) and projected (hatched) population for Rio Rancho, New Mexico.

Source: U.S. Census Bureau, 2016.

The focus of this research is the provision of a sustainable potable water supply for current and future residents of Rio Rancho. It explores some of the possible options that are available for resolving significant water resource problems and examines the specific techniques that are currently being used by the City of Rio Rancho to extend the life of a very limited water supply. Finally, this research summarizes the effectiveness of strategies employed thus far and outlines future water management options.

\section{Water Resource Issues at Rio Rancho}

\section{Site history and description}

Rio Rancho began in 1961 as one of AMREP's (American Realty and Petroleum Company) interstate land sales operations (Wolff 1973). The original site included 55,000 acres of land that is located along the northwestern city limits of Albuquerque on the West Mesa of the Rio Grande (Fig. 2). 


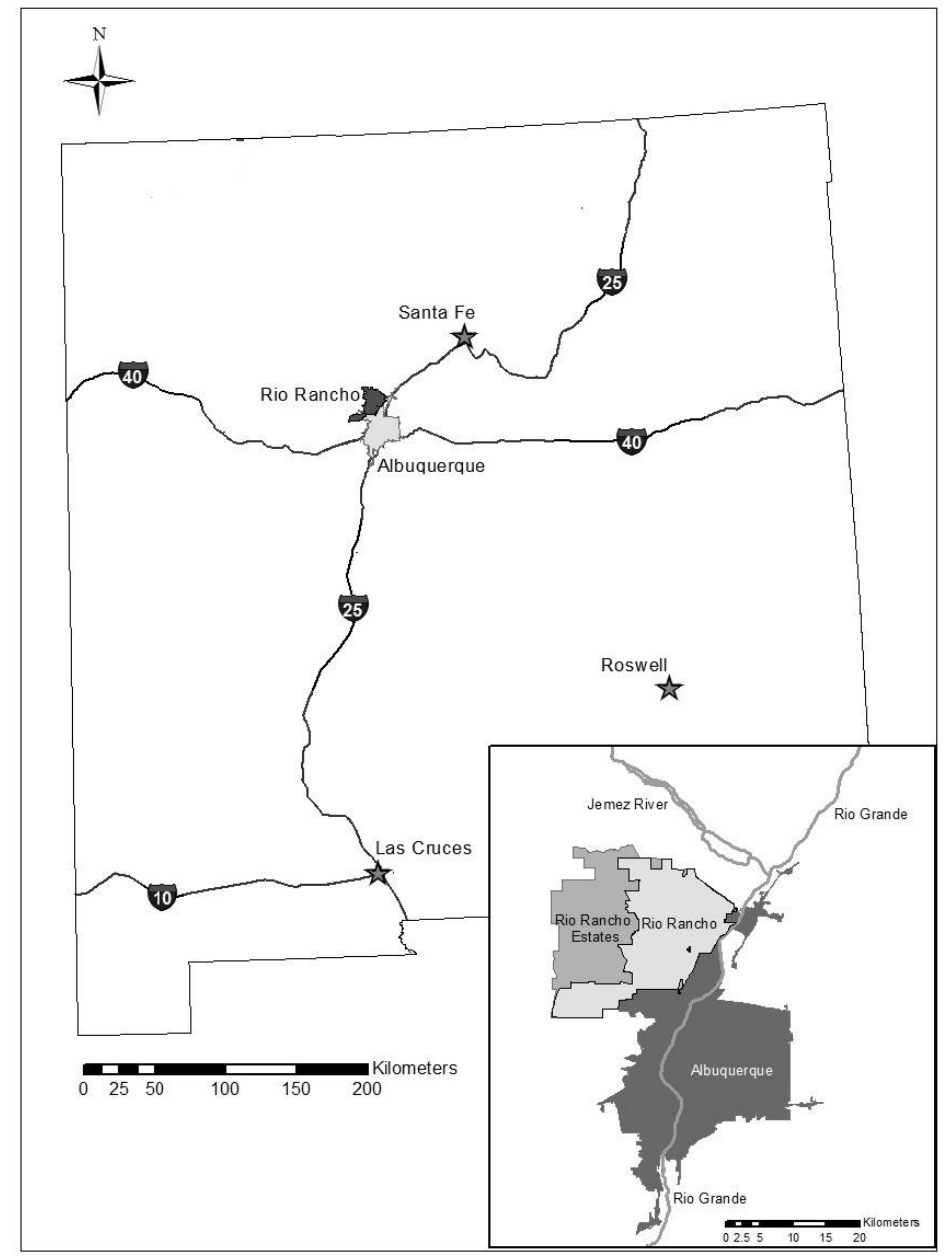

Figure 2. Location of Rio Rancho relative to major urban areas in New Mexico. Inset depicts Rio Rancho (incorporated) and Rio Rancho Estates (unincorporated) relative to nearby Albuquerque.

Source: U.S. Geospatial Data Gateway, City of Rio Rancho, 2016.

The company purchased an additional 35,000 acres in 1971 and subsequent acquisitions brought the total acreage to more than 91,000 acres. A favorable location and a vast tract of land provided the developers an opportunity to sell thousands of home sites and create a tremendous potential for population growth. This growth potential is particularly important as the demographics of Rio Rancho change from a retirement community to a new generation of young families. 
The prior platting of the bulk land subdivision known as "Rio Rancho Estates" created well over 100,000 lots that were laid out in a pre-determined grid iron pattern that created numerous problems, including inefficient patterns of growth, scattered development, inadequate infrastructure and absentee land ownership (Wolff 1972). Because development has been scattered, rather than in phases, the cost of providing services has been increased dramatically. Since the original developers made services available only to a small core area, those families or individuals wishing to build a home outside the developed core must provide their own services. As a result, there are thousands of homeowners that use septic systems and individual water wells on small lots within this vast subdivision, much of which is unincorporated. The "developed" portion of Rio Rancho Estates was incorporated in 1981 and became the City of Rio Rancho. Consequently, the vast original land development site is divided into two separate entities. The vast, virtually uninhabited area to the west of the existing city limits remains as Rio Rancho Estates (Fig. 2, inset). Even within the current Rio Rancho city limits, over 2,500 families use individual water wells as their only source of water supply (M. Wrage, March 2015, personal communication).

From a natural resource perspective, Rio Rancho suffers from several environmental limitations including low rainfall (less than 10 inches per year) and extremely limited surface-water resources, a deep water table which makes digging a well extremely expensive and groundwater contamination from naturally occurring arsenic. Furthermore, the area suffers occasional dust and sand storms (due to extreme aridity) and is crisscrossed by a network of deep gullies (arroyos) that are susceptible to flash flooding and erosion.

Providing an adequate water supply in this dry environment is difficult, particularly since Rio Rancho has such a high population growth potential and limited options for obtaining "new" sources of water. Since Rio Rancho is such a new city, incorporated in 1981, it has not had the opportunity to find creative ways to acquire water rights from other sources of supply. This more than likely means that the aquifer currently being tapped by Rio Rancho is the only source of water supply in the future. Currently, the City's rapid population growth and the everincreasing levels of water use in the Albuquerque metropolitan region are outpacing the aquifer's recharge rate (Selcraig 1994). This is causing the water table beneath the city to drop. If the imbalance continues and nothing is done to restore the aquifer, wells will eventually go dry and the land will sink (Chrisholm 2012). Land subsidence associated with groundwater pumping from aquifers, especially in high population areas, has been well documented (Guo et al. 2015, Kearns et al. 2015). 


\section{Water Supply and Demand}

The City of Rio Rancho obtains its water supply from 17 deep groundwater wells located throughout the city (Fig. 3). Groundwater is pumped from the Santa Fe Group Aquifer, a layer of unconsolidated deposits that range in thickness from 1,400 feet at basin margins to approximately 14,000 feet in localized areas in the center of the basin (Bexfield 2010). At Rio Rancho, the water table drawdown ranges from 60 to as much as 200 feet in some locations and the current depth to water is approximately 1000 feet (Bartolino and Cole 2002). Most of the City's production wells are drilled to a depth of 1,000 to 3,000 feet at a cost of approximately \$9 million per well (City of Rio Rancho 2012).

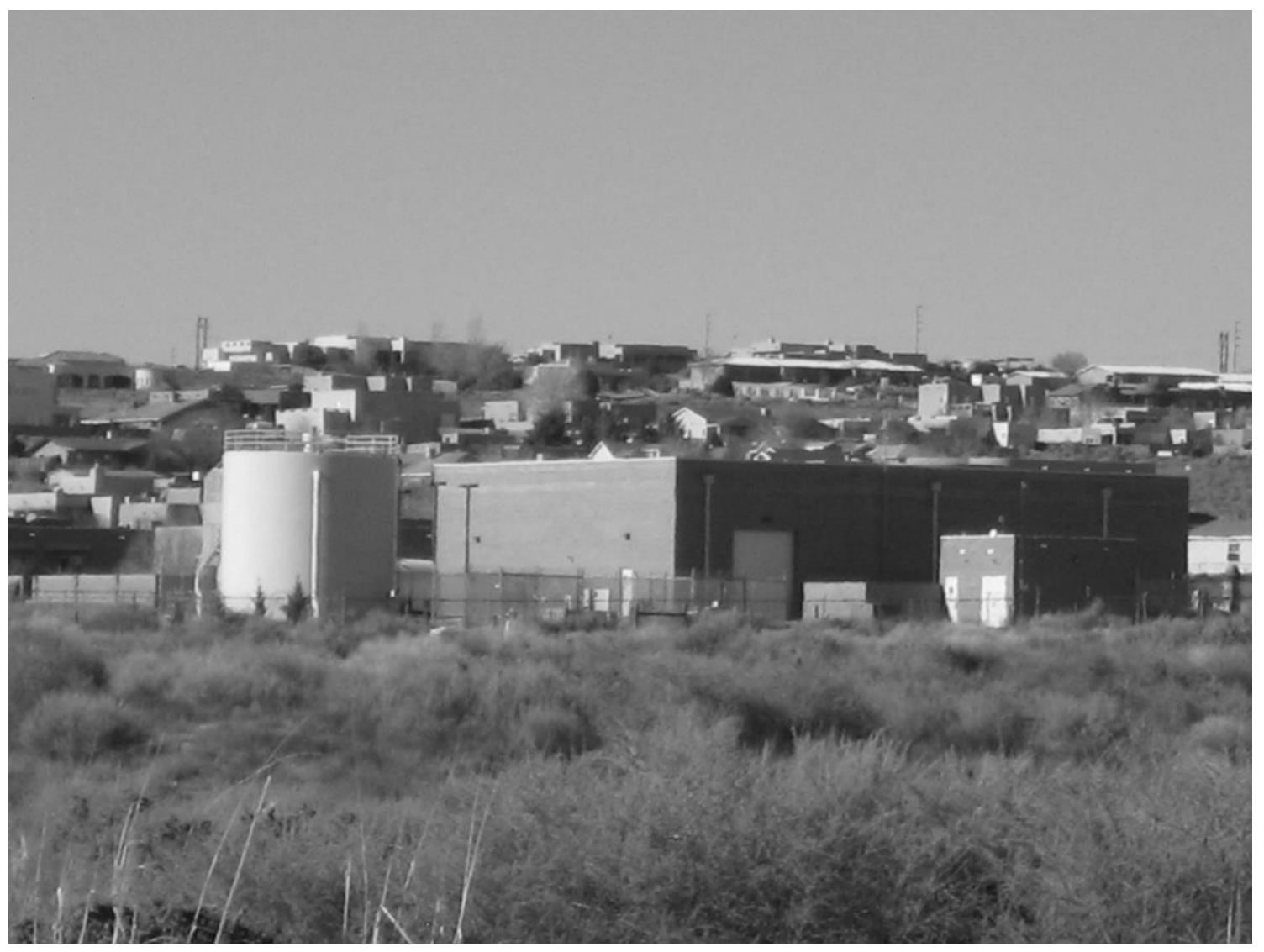

Figure 3. Ground view of reservoir tank and building housing one of the 17 wells currently used as water supply to Rio Rancho.

Source: Marian Wrage, Environmental Programs Manager, City of Rio Rancho, 2016. 
This aquifer is used by many communities within the Middle Rio Grande Basin as their primary and possibly only source of drinking water (Bartolino and Cole 2002). Since the volume of water within this aquifer is limited, protection from "overuse" and contamination become extremely important (S. Sensanbaugher, 2011, personal communication). While the City of Rio Rancho is searching for additional sources of water supply, the Santa Fe Group Aquifer is currently the only source of supply. Based on Rio Rancho's population growth projections, water demand is expected to triple over the next 40 years. An obvious and alarming problem emerges when one considers the future water availability in comparison to growth potential and demand.

Since its incorporation in 1981, water use at Rio Rancho increased substantially but began to level off in 2001. This increased use coincided with significant increases in population. The current volume of water use exceeds 3.5 billion gallons per year. While production increased significantly from just over 3.2 billion gallons in 1997 to more than 3.5 billion in 1999, it subsequently leveled off in part because of conservation efforts and reduced usage by industry. The stable use trend at slightly more than 3.5 billion gallons per year is in spite of a significant increase in the number of residential accounts (D. Hunter, July 2011, personal communication). Water use at Rio Rancho is categorized as residential, commercial, industrial, city/public, and non-revenue water. As depicted in Figure 4 , single family residential is by far the greatest user.

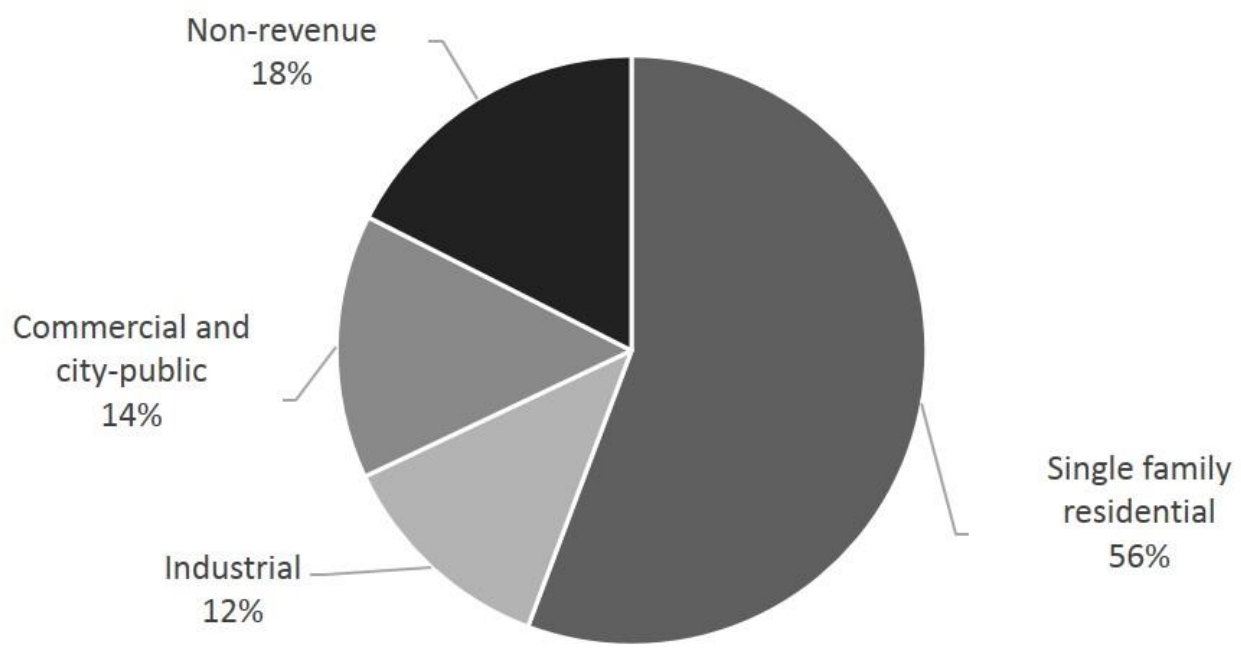

Figure 4. Water usage by category for Rio Rancho, New Mexico.

Source: Marian Wrage, Environmental Programs Manager, City of Rio Rancho, 2016. 
This is not surprising since many pre-platted communities, established by bulk lot sales operations, emphasized the selling of residential lots particularly during the early stages of development, when the primary motivation was profits obtained from lot sales (Stroud and Spikowski 1999).

It seems unlikely that the current water supply will remain adequate in the future, given proposed population growth and current usage patterns. If the same usage pattern continues through 2040, the volume of water required for 160,000 residents (the projected population) would be over 10 billion gallons per year, or nearly 31,000 acre-feet per year, an amount far exceeding water supply availability (M. Wrage, March 2015, personal communication).

\section{Water Quality}

When assessing the ability of a city to provide a sustainable supply of drinking water for its citizens, it is crucial to consider water quality. This is especially true when there is little or no access to an alternative water supply, as is the case at Rio Rancho. Water contaminated with pollutants like nitrates or heavy metals can be very expensive to treat. This expense can decrease the viability of a sustainable water supply. The groundwater supply for Rio Rancho is generally of good quality (City of Rio Rancho 2015) with the majority of detected contaminants falling below the Maximum Contaminant Level (MCL) established by the United States Environmental Protection Agency (EPA). One important exception is arsenic, a contaminant that has been measured at levels exceeding the MCL (City of Rio Rancho 2004).

Arsenic is known to cause cancer in humans at high concentrations and is currently listed as the highest priority on the priority list of hazardous substances (ATSDR 2016). Because of the hazards associated with arsenic exposure, the EPA lowered the MCL for arsenic from $0.05 \mathrm{mg} / \mathrm{L} \mathrm{(50} \mathrm{parts} \mathrm{per} \mathrm{billion)} \mathrm{to} 0.01 \mathrm{mg} / \mathrm{L}$ (10 parts per billion) in 2001. Public water systems were given until January 2006 to meet this higher standard. EPA's standard balances the current understanding of arsenic's possible health problems against the cost of removing arsenic from drinking water.

Unfortunately, arsenic is especially common in areas of the southwest, with New Mexico having some of the highest natural concentrations in the United States. Initially, twelve of the City's wells (untreated water) had arsenic at levels exceeding the new MCL of $0.01 \mathrm{mg} / \mathrm{L}$ (M. Wrage, March 2015, personal communication). Rio Rancho has been proactive in dealing with this issue. They evaluated treatment technologies and implemented an arsenic removal program designed to meet and even exceed EPA standards. This treatment has been effective with arsenic concentrations in treated water ranging from 0.003 to $0.012 \mathrm{mg} / \mathrm{L}$ in recent years (City of Rio Rancho 2014b). A single measurement $(0.012 \mathrm{mg} / \mathrm{L})$ exceeded the MCL and a confirmation sample taken from the same well was below the MCL. 
While this single high measurement does not violate EPA compliance (based on average annual concentrations of arsenic), Rio Rancho did increase monitoring frequency in response to this elevated concentration. This increased monitoring revealed no samples in exceedance of the MCL for arsenic (City of Rio Rancho 2015).

While effective, the arsenic removal techniques that have been implemented can add significantly to the City's water supply costs. In 2010, for example, the City spent \$1,333,600 for arsenic removal (City of Rio Rancho 2015). Increased oversight and stewardship have resulted in a considerable decrease in the cost of arsenic removal, with a projected cost of $\$ 700,600$ for fiscal year 2017 (City of Rio Rancho 2015). Still,arsenic removal along with other purification efforts and the expense of pumping are major contributors to the overall cost of potable water for residents of Rio Rancho (M. Wrage, March 2015, personal communication).

\section{Current Water Management Strategies}

The City of Rio Rancho has adopted a community vision designed to provide an innovative and proactive approach to provide a sustainable water future. The mission statement of the water resource management strategy points out that Rio Rancho will be a model community in the desert southwest with a reuse program that effectively secures its water future. Because all of New Mexico's groundwater basins have been appropriated and no additional water rights can be allocated (Brockman 2009), acquisition of an additional water supply seems unlikely. Consequently, management strategies employed by the City include improved conservation of water, reduction of non-metered water loss and increased education about water usage and management strategies (City of Rio Rancho 2004; J. Korkosz, April 2011, personal communication).

\section{Conservation}

Water conservation helps delay or avoid the need to acquire additional water and water rights and provides an opportunity for population growth to continue. Thus, conservation is a key component in Rio Rancho's Water Management Plan. Several conservation options are available including reducing residential usage of water via installation of water conservation hardware and appliances, improving landscaping practices by converting turf to xeriscaping, installing moisture sensing irrigation systems and installing rainwater harvesting systems, and reusing treated water by installing efficient gray water reuse systems and participating in aquifer recharge. (M. Wrage, March 2015, personal communication).

Because of New Mexico's arid climate and because water is a precious and limited resource, xeriscaping is a logical conservation choice for residents of Rio Rancho. Xeriscaping can be defined as water efficient landscaping appropriate to the natural environment with an end goal of creating a visually attractive landscape 
using water efficient plants. Properly maintained, a xeriscape can easily use less than one-half the water of a traditional landscape. Sovocool et al. (2006) found that residences in southwestern Nevada which xeriscaped their lawns had a 30\% reduction in yearly total water consumption as well as increased savings in time, labor and costs associated with maintenance of a traditional turf grass lawn. Xeriscaping coupled with a well-planned and well maintained irrigation system can reduce the water usage of a traditional landscape even further. Properly adjusting irrigation systems should ensure continued water savings. Trees, shrubs, flowers and ground cover can be watered efficiently with low-volume drips, emitters, sprayers and bubblers (Albuquerque Bernalillo County Water Utility Authority 2011).

The City also encourages its residents to take advantage of rainwater harvesting techniques as an additional means of conservation. Harvested rainwater is a free source of water and the materials required for harvesting are simple and inexpensive. Furthermore, water harvesting reduces the load on storm-water systems and decreases the use of potable municipal water for non-potable needs. Finally rainwater harvesting can aid in reducing water bills (City of Rio Rancho 2014c)

\section{Reduction of non-revenue water loss}

A significant amount of pumped water is lost from leaks and other un-metered uses. This water loss, referred to by the City as non-revenue water, is determined by calculating the difference between the municipal well meter readings (water pumped) and metered water sales. Specific examples of non-revenue water include water from system leaks, un-metered fire-fighting, irrigation, well flushing, and system flushing. According to the Utilities Department, non-revenue water has varied considerably in the past and has increased during the last few years. Based on industry standards, non-revenue water should be less than $10 \%$ of total water pumped. While some of the uses can never be eliminated, a reduction of this type of "water use" will create additional water supply for the community.

The City has begun updating their water delivery infrastructure by replacing aging polyethylene lines with pipes composed of new, longer-lasting materials. So far, this replacement has resulted in a decrease in water lost to line leaks of over 5.5 million gallons annually, a reduction of 41\% (City of Rio Rancho 2014b). Line replacement should also help to maintain/improve water quality by reducing the likelihood of bacterial contamination introduced into the water supply from cracks or breaks in aging water lines. The infrastructure update began in 2014 and is projected to continue until all polyethylene lines are replaced.

The city is also attempting to combat waste through better enforcement of the existing water conservation code. A hotline was established which allows users to report incidents of water waste. If a complaint is made, a technician performs a 
field inspection and issues a citation if necessary (City of Rio Rancho 2016a). Correcting the problem and encouraging compliant behavior would do much to eliminate waste and extend the life of existing supplies.

\section{Education and Community Outreach}

An additional way in which Rio Rancho is attempting to manage its limited water supply is by increasing education and outreach to the community. Free water audits are available for residential users. These audits are important since many users are unaware of the volume of water they use or the opportunities for conservation. Utility supported water audits serve as a method for educating the public and demonstrating the possibilities for reducing consumption. Space is provided at City facilities for demonstrating new equipment and water conserving hardware for homes and businesses. City facilities also use xeriscaping and rainwater harvesting as part of the landscaping and design of public buildings.

Educational opportunities have been expanded to include not just adult water users, but also school children of all ages. To improve water resource education, the City established the annual Children's Water Festival, which serves to educate students and teachers about water resources, conservation and management tools in a fun and interactive atmosphere. By educating these students who can then share their knowledge at home and with extended family, the City hopes to reach a much larger audience of current water users than it might through adult-oriented outreach options (City of Rio Rancho 2016b). The City also established the 'Every Drop Counts' award, presented to middle or high-school students whose science fair projects best represent the category of water conservation, water efficiency or water quality (City of Rio Rancho 2016b).

According to Larry Webb, head of the City's Utilities Division, Rio Rancho is leading New Mexico water conservation and environmental efforts by example. An important part of these efforts are the volunteer master gardeners that give advice on proper xeriscaping techniques. The idea is to conserve precious water today to ensure a healthy water future for one of New Mexico's fastest growing communities. To assist in these efforts, the Rio Rancho Utilities Division provides brochures on xeriscape landscaping, rebates for the installation of water-saving devices, free leak detection and water use audits, along with other water saving advice provided by the city (City of Rio Rancho 2007; L. Webb, June 2013, personal communication).

\section{Improvements in Sustainability and Water Quality}

One of the most important conservation strategies employed by the City is to gradually lower its per capita use, particularly in the residential use sector. In its 2004 Water Resources Management Plan, the City's goal was to reduce per capita water usage from 181 gallons per capita per day (gpcd) to 150 gpcd. This goal was 
achieved for the first time in 2005, when the City's per capita use was 147.58 gallons per day. In view of this water conservation success and the ongoing need to reduce daily water use even more, the City established a new goal of 135 gpcd for system wide use with a target date of 2017. The goal was included in the City's implementation policy for the next five-year planning period (City of Rio Rancho 2014a) and was met by 2014 when system-wide per capita usage was reduced to 122.64 gpcd (Fig. 5).

Because the residential sector represents the majority of system-wide usage, a key component of the successful reduction in per capita usage is reflected by reductions in this category. Single family residential usage in Rio Rancho has declined from 87.38 gpdc in 2007 to 65.68 gpcd in 2015 (Fig. 5). It should be noted that this usage does not include the roughly 2,500 residences with private wells.

Reductions in water use thus far have been attributed to policies embedded in the Water Resource Management Plan. Specific components included evaluation of causes of unaccounted for water (non-revenue water), passing an effective enforcement mechanism, providing free home and business water conservation audits, encouraging the construction of more water-efficient homes, promoting and implementing water conservation initiatives, promoting public awareness by the placement of graphical displays that highlight water conservation initiatives, setting examples for water conservation by using attractive xeriscaping at all municipal sites at public parks, encouraging onsite rainwater harvesting and irrigation controls at residential sites, and expanding the current rebate program to include incentives and/or rebates to existing customers for investing in water conserving practices (M. Wrage, January 2016, personal communication).

The City has an ongoing plan to effectively treat its groundwater, ensuring a high quality water supply. Treatment efforts have been successful with all contaminants, including bacteria, heavy metals and organic contaminants, consistently measuring far below the MCLs established by the EPA. This includes the most potentially hazardous contaminant, arsensic, which has consistently been measured at or below the MCL (City of Rio Rancho 2015). Clearly, the City has been successful in maintaining and even improving the quality of a limited and potentially impaired water supply, a crucial part of establishing a sustainable resource.

As part of an ongoing effort to meet water needs, the City of Rio Rancho revised its Water Management Plan in 2014. The revised plan evaluated implementation policy options and established a prioritization for meeting water supply needs. The following eight policies were given the highest priority ranking: 1 . to reduce nonrevenue water, 2 . to continue providing home and business water audits, 3 . to provide additional staff and resources for the water conservation program, 4. to continue implementing the water reuse policy, 5. to actively negotiate with the Office of the State Engineer (OSE) and the New Mexico Environment Department 
(NMED) regarding aquifer storage and recovery and return flow credits, 6. to identify new sources of water, if any are available, 7. to identify funding for new infrastructure, and 8. to take action to limit the potential for ground water contamination from septic systems (City of Rio Rancho 2014a). These and other efforts are ongoing and will help to extend the life of a very limited water supply.

\section{Future Water Management Strategies}

Unfortunately, as the Office of the State Engineer points out, the demand for water in Rio Rancho exceeds the supply. There is no new water available within many of New Mexico's over-appropriated basins. Water supply problems are intensified because of recent drought conditions, in-stream flow demands to protect endangered species, interstate compact deliveries, and the possibility of other mega-developments that are currently being planned within the Albuquerque metropolitan area (Provost 2015). These conditions make conservation more important than ever. Future water management and conservation options include a water reuse strategy that seeks to maximize beneficial use of current supplies through the recycling of highly treated wastewater (reclaimed water), an aquifer recharge strategy and implementation of policies designed to protect the quality of the current groundwater resource. These options can serve as a key strategy to conserve and extend the life of a very limited water supply and increase the sustainability of Rio Rancho. The City is committed to the efficient use of its water resources and is aware of the significance of developing these strategies as an important and integral part of its overall water resources planning effort.

Since water use is expected to exceed supply within the next few years, the City is implementing best management practices for the use of reclaimed wastewater to sustain the community's limited water supply (Parametrix and Wilson \& Company, Inc. 2008). The water reuse strategy is designed to maximize the use of reclaimed water within the City's service area. Reclaimed water would be used for landscape irrigation and to meet commercial and industrial needs to help conserve the limited available supply of potable water. Converting existing water demands such as turf irrigation at parks, schools, and sports fields will provide immediate reductions in pumping by replacing these demands with safe non-potable reclaimed water. Fortunately, the reclaimed water supply will increase as economic and population growth occurs in the community and will provide a drought-proof and reliable supply to meet future non-potable demands. 
A

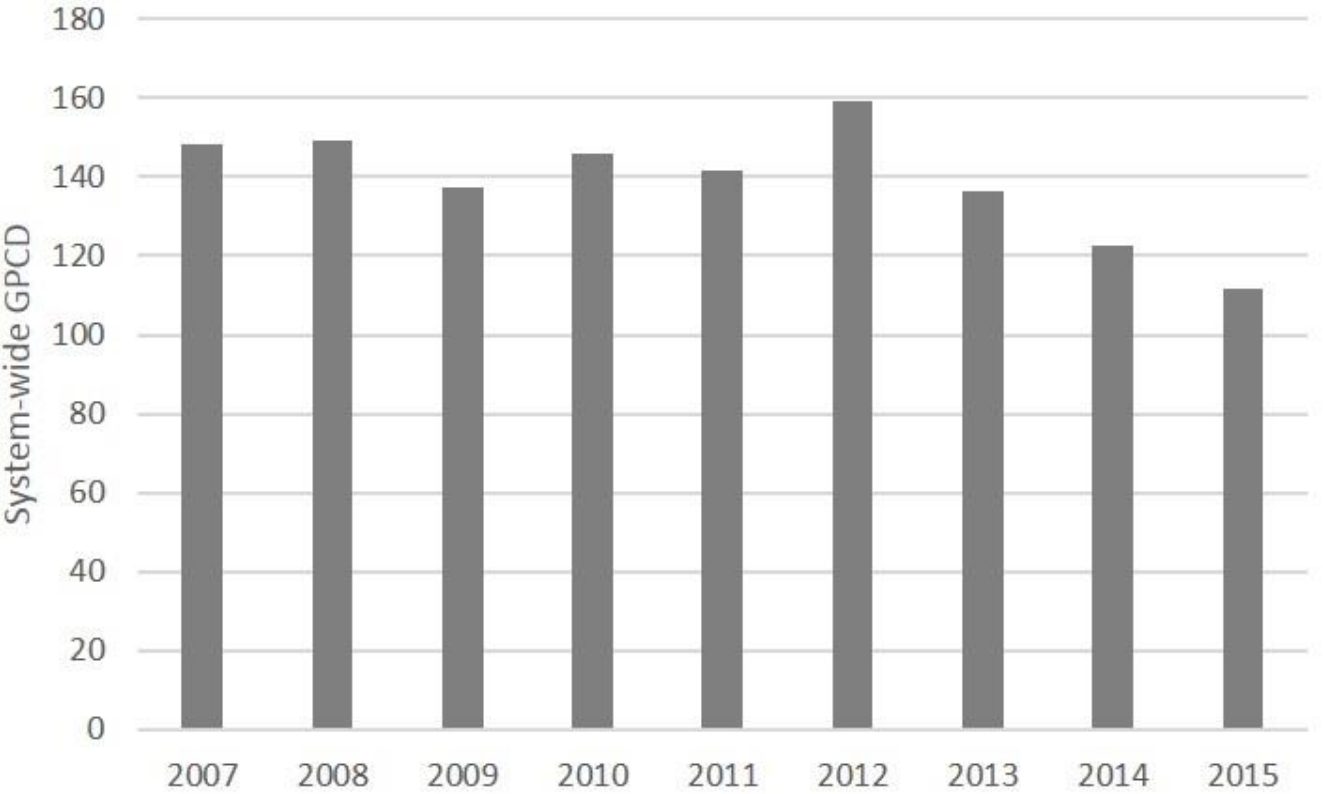

B

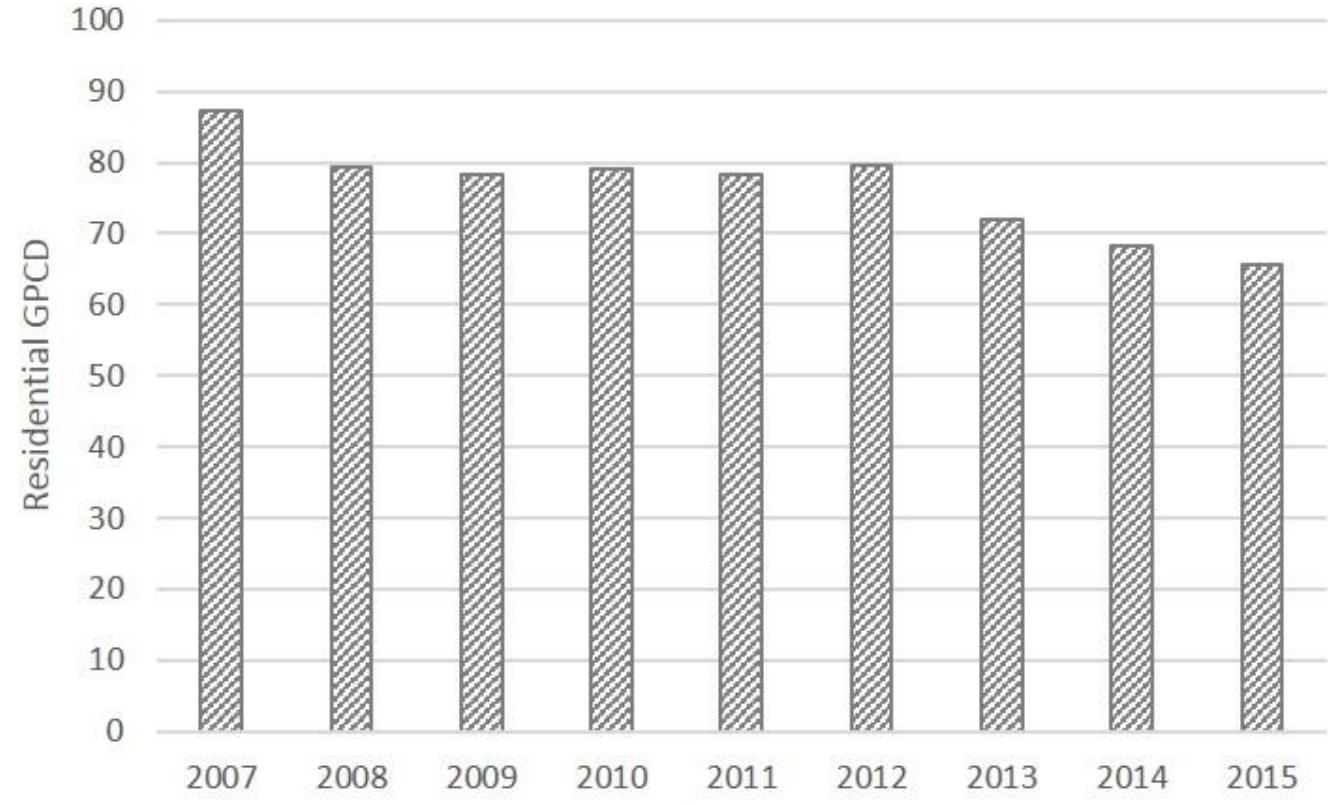

Figure 5. A) System-wide per capita water usage at Rio Rancho, New Mexico, 20072015. B) Residential per capita water usage at Rio Rancho, New Mexico, 2007-2015. Usage does not reflect residences with private wells.

Source: City of Rio Rancho, Utilities Division, Consumer Confidence Report, 2015. 
The City is also working to augment and replenish groundwater supplies by using aquifer recharge. The goals are to improve aquifer sustainability, reduce surface water depletions in the Rio Grande and Jemez River and reduce the local rate and magnitude of groundwater declines (City of Rio Rancho 2011). Aquifer recharge has been found to be an effective means of managing a limited groundwater supply in other parts of the world (Hernández et al. 2011, Sheng 2005, Barnett et al. 2000). Not only are limited water supplies augmented, but economic costs to municipalities and users are often reduced. A cost-benefit analysis of an aquifer recharge program in the Las Vegas Valley, Nevada, U.S.A. found that members of the groundwater management program had an annual savings of $\$ 700$ per member (Donovan et al. 2002).

The recharge program at Rio Rancho is designed and being implemented to maximize the beneficial use of all available water sources including reclaimed wastewater. When the demand for reuse water is low, the purified water can be stored in surface reservoirs or subsurface aquifers. Aquifer storage offers the advantage of nearly infinite capacity, preservation of the quality of the purified water source, and the reduction or elimination of water losses associated with evaporation from open surface reservoirs (Arshad et al. 2014). The City's aquifer recharge site consists of one injection well surrounded by 2.5 acres of fenced cityowned property. The site has an extensive groundwater monitoring network and, at full capacity, the direct injection facility can replenish the groundwater system at a rate of 1 million gallons per day. This projection is based on initial testing of the injection well (City of Rio Rancho 2013).

Prior to direct injection, the reclaimed water will undergo an on-site advanced water treatment (AWT) process. As part of the City's efforts to ensure that the groundwater supply is not impaired by contaminants or pathogens, several treatment technology options were assessed, including physical separation through reverse osmosis ( $\mathrm{RO})$ membranes, advanced oxidation processes using ozone and hydrogen peroxide, adsorption processes such as granular activated carbon (GAC), biologically activated carbon (BAC), and final disinfection. The City selected the ozone-based advanced oxidation process followed by a BAC-GAC step prior to injection. This process has been widely used for drinking water treatment by other municipalities and the City is confident that this approach will protect water supply (City of Rio Rancho, 2013).

The City will continue to implement several policies designed to protect the quality and integrity of the groundwater that supplies drinking water. Some of the most significant include actively managing domestic wells, including monitoring existing wells and prohibiting the drilling of wells where there is reasonable access to public water supply (U.S. Water News Online 1996). Property owners will be prompted to convert to the city system when water utilities become available. Property owners will also be asked to properly plug and seal their domestic well for 
groundwater protection. Moreover, the City will take action to limit and reduce potential sources of groundwater contamination. Waste water utilities will be extended to areas currently not served and property owners will be encouraged to connect to the City system. It is suggested by the authors that the City seriously consider making connection mandatory for residents and lot owners if and when new services (water and sewer) are provided.

To further enhance the City's water management strategies, changes are needed in policies related to regulation of water resources. As a result, the City will work with the State Engineer's Office and lobby the State Legislature to expand the local authority to permit and regulate domestic wells. The City supports a change in State Law that would reduce the allocation for new wells from 3-acre feet to 1.5-acre feet per year (City of Rio Rancho, 2004). Moreover, Rio Rancho would also like to implement specific policies aimed to support continued growth in a sustainable manner. New development whether residential, commercial, or industrial or public, will be evaluated and approved only if water availability is demonstrated and documented.

There is a need to perform a review of all planning and zoning requirements as they relate to water use (J. Korkosz, April 2011, personal communication). Revisions should be made to reflect the policies of the Water Resources Management Plan. Examples of important changes include the following: requiring businesses that use large volumes of water to file a water conservation plan with shared approval by City Utilities and City Development; requiring a conservation plan to be a part of every new development's master planning requirements; and requiring an increase in the number and frequency of neighborhood parks that are irrigated with reclaimed water.

Improvements are also needed in the way in which the City charges its customers for the water they use. The City will reevaluate the water rates structure and propose increases to cover, in part at least, the cost for the purchase of water rights and the protection of groundwater supplies. The rates structure will be designed to require users of "excessive" amounts of water to pay more. One option being considered is an inclining block rate that imposes rates based on water usage. While the current rates include a minimal increase for large volume users, it is inadequate or ineffective for curbing excessive use.

Based on some of the previously discussed ordinances and policies, an important area of potential water conservation is related to new development. Consequently, new development should be required to incorporate the following: xeriscaping, water conservation hardware, low-flush toilets, hot water recirculation, and low water-use appliances. New development will also be encouraged to use moisture sensing irrigation systems, rainwater harvesting systems, gray water reuse systems, and other options. 


\section{Summary and Conclusions}

City officials at Rio Rancho are faced with a number of very troubling issues concerning the establishment of a sustainable and affordable potable water supply. Many of the difficulties are associated with its original layout and design since the project (the City) began as a lot-sales subdivision. This largely accounts for the current platting and ownership pattern of undeveloped land within the Rio Rancho municipal limits and is an impediment to sound suburban growth. Furthermore, this creates significant problems for water resource management. One very serious problem has been leap frog development, which extends the distance and the cost of providing necessary infrastructure, including water and sewer lines to lots. In turn, this encourages lot owners in more distant locations to rely on individual wells and septic systems, a potential threat to the quality of the available groundwater resources.

Hopefully, the City's relatively new Vision 2020 "growth nodes" approach that is preferred by City officials will create more efficient patterns of growth, mitigate the negative impacts of sprawl by limiting the development of nonresidential uses outside designated growth nodes, promote infill, limit strip commercial development, and incorporate phasing schedules, installation costs and maintenance guarantees into the land development process (Stroud and Tollefson 2003).

It is important to note that the Utility Department recognizes the need to make changes if the City is to meet the demands for water in the future. Improvements to the water management plan are already underway and include identifying infrastructure requirements, reevaluation of the water rate structure, protection of limited groundwater supplies, and planning for future expenses related to water rights acquisition, transfer and management.

Plans for future development in the City will address infrastructural needs by making sure that utility extensions occur in an orderly and timely manner. One of the key issues for the provision of services (utilities) occurs in response to a City driven pattern of development rather than responding to demands created by individual lot owners or developers. Developers tend to prefer 'undisturbed' parcels of land that may be outside designed growth nodes (Schwab 1997a and 1997b). Such development could intensify problems associated with suburban sprawl, particularly in this arid environment (Katz 1999; Fulton and Shigley 2002).

Currently all available water rights have been acquired and additional water rights are unlikely to become available. Therefore, rather than rely solely on the retirement, acquisition, and transfer of additional water rights to expand the water supply, it is much more cost-effective to increase the efficiency of the use of existing water supplies. The key to greater efficiency is through the implementation of a water reuse plan which emphasizes the maximization of the use of reclaimed 
water. This water could meet a variety of needs and would eliminate the use of potable water for landscape irrigation (golf courses, for example). Reclaimed water would also be used where possible to meet commercial and industrial needs. The City strongly supports the implementation of a water reuse strategy as a means to reduce the pressure on groundwater supplies.

The City also plans to move forward with its plan for aquifer recharge with treated water. Artificial recharge would help replenish and protect the aquifer. Both infiltration and injection methods will be used. The City will use advanced technologies to ensure that the re-injection does not compromise groundwater quality. A recharge system is currently being tested and the initial results are very positive.

Overall, substantial improvements have been made in the development of a sustainable water supply in Rio Rancho. The water conservation and management strategies currently employed have resulted in an overall decrease in per capita water usage, despite continued increases in water demand due to a growing population. Future planned conservation and management strategies and policy initiatives show considerable promise to further extend the life of a limited resource. Rio Rancho serves as a model, not just to other cities in the American West, but to urban and suburban communities throughout the world. As the global population continues to grow and water resources become increasingly limited, especially in urban areas where population growth is concentrated, employment of management strategies similar to those currently employed and proposed by the City of Rio Rancho could be an effective means of developing more sustainable usage patterns world-wide.

Agency for Toxic Substances and Disease Registry. 2016. Priority List of Hazardous Substances. http://www.atsdr.cdc.gov/spl/.

Albuquerque Bernalillo County Water Utility Authority. 2011. Xeriscaping, the complete how-to guide. 52p. Available at http://www.ose.state.nm.us/WUC/Albqbrochures/Xeric-Guide.pdf.

Allan, L., Kuder, B., Oakes, S.L., 1976. Promised Lands. Vol. 1, Subdivisions in Deserts and Mountains. New York, Inform.

American Society of Planning Officials, Conservation Foundation, Urban Land Institute, and Ragatz Assoc., Inc. 1976. Subdividing Rural America: Impacts of Recreational Lot and Second Home Development. Washington, D. C.: Council of Environmental Quality.

Arshad, M., Guillaume, J.H.A., Ross, A., 2014. Assessing the feasibility of managed aquifer recharge for irrigation under uncertainty. Water 2014(6):27482769. 
Barnett, S.R., Howles, S.R., Martin, R.R., Gerges, N.Z., 2000. Aquifer storage and recharge: innovation in water resources management. Australian Journal of Earth Sciences 47:13-19.

Bartolino, J.R., Cole, J.C., 2002. Ground-water resources of the Middle Rio Grande Basin. United States Geological Society Circular 1222.132 p. http://pubs.usgs.gov/circ/2002/circ1222/

Bexfield, L.M., 2010. Sec. 11. Conceptual understanding and groundwater quality of the basin-fill aquifer in the Middle Rio Grande Basin, New Mexico, in Thiros, S.A., Bexfield, L.M., Anning, D.W. and Huntington, J.M. eds., 2010, Conceptual understanding and groundwater quality of selected basin-fill aquifers in the Southwestern United States: U.S. Geological Professional Paper 1781, 288 p.

Brockman, J.C., "Overview of New Mexico's Groundwater Code," paper presented at the $27^{\text {th }}$ Biennial Groundwater Conference and the $18^{\text {th }}$ Annual meeting of the Groundwater Resources Association of California, Oct. 6 -7, 2009, Sacramento, CA.

City of Rio Rancho, 2004. Water Resources Management Plan, Final Report and Policy Recommendations.

City of Rio Rancho, Utilities Division, 2007. Water-Wise News and Events for Rio Rancho Utility Customers.

-., 2011. Aquifer Storage and Recovery Project Update. In Spring 2011 Newsletter.

-., 2012. Consumer Confidence Report

-., 2013. Fact Sheet: Direct Injection Aquifer Recharge Demonstration

-., 2014a. Water Resource Management Plan: Implementation Plan Update.

-., 2014b. Consumer Confidence Report.

-., 2014c. Free water: Yours for the harvesting! In Fall 2014 newsletter.

-., 2015. Consumer Confidence Report

City of Rio Rancho, Environmental Programs Section. 2016a. Water Waste Complaints. http://www.rrnm.gov/index.aspx?NID=282 Accessed 24 January 2016.

-., 2016b. Education and Outreach Program http://www.rrnm.gov/index.aspx?NID=177 Accessed 28 January 2016.

Chrisholm, C., 2012. From toilet to tap: Rio Rancho plans to pour effluent into the aquifer. Alibi.com 21(8), February 23 - 29, 2012. http://alibi.com/news/40477/articles.html 
Dodrill, D.E., 1993. Selling the Dream. Tuscaloosa: University of Alabama Press. Donovan, D.J., Katzer, T., Brothers, K., Cole, E., Johnson, M. 2002. Cost-benefit analysis of artificial recharge in Las Vegas Valley, Nevada. Journal of Water Resources Planning and Management September/October 2002: 356-365.

Elliott, D.L., 1997. Obsolete subdivisions and what to do about them. Technical Report No. 12, The Rocky Mountain Land Use Institute, College of Law, University of Denver, Denver, Colorado.

Fulton, W., Shigley, P., 2002. Operation desert sprawl. In Geography, Gerald Ritzl (ed.), pp. 81-84. Guilford, Connecticut: McGraw-Hill/Dushkin.

Gleick, P. H. (ed), 1993. Water reserves on Earth. Water in Crisis: A Guide to the World's Freshwater Resources. Oxford University Press 13p., Table 2.1

Guo, H., Zhang, Z., Cheng, G., Li, W., Li, T., Jiao, J. 2015. Groundwater-derived land subsidence in the North China Plain. Environmental Earth Sciences 74(2):1415-1427.

Hernández, M., Tobella, J., Ortuño, F., Armenter, J. Ll. 2011. Aquifer recharge for securing water resources: the experience in Llobregat river. Water Science and Technology 63(2):220-226.

Katz, B., Bradley, J., 1999. Divided we sprawl. Atlantic Monthly 284(6):26-42.

Kearns, T.J., Guoquan, W., Yan, B., Juajun, J., Dongje, L. 2015. Current land subsidence and groundwater level changes in the Houston metropolitan area (2005-2012). Journal of Surveying Engineering 141(4):501002-1-501002-16.

Lucero, L., Tarlock, A.D., Water supply and growth in New Mexico: same old, same old or a new era?" Natural Resources Journal 43:803-835.

Maupin, M.A., Kenny, J.F., Hutson, S.S., Lovelace, J.K., Barber, N.L., and K.S. Linsey 2014. Estimated use of water in the United States in 2010. U.S. Geological Survey. Circular 1405. $56 \mathrm{p} \mathrm{http://dx/doi.org/10.3133/cir1405.}$

Parametrix and Wilson \& Company, Inc., 2008. Effluent Water Reuse System, Draft Environmental Information Document for the City of Rio Rancho, Rio Rancho, New Mexico.

Provost, C., Bienvenu, L., 2015. Why does Barclays want to build a city in the middle of the New Mexico desert?" The Guardian, pp. 1 - 6. http://www.theguardian.com/cities/2015/may/19/barclays-city-new-mexicodesert-santolina-urban-sprawl-albuquerque.

Salvensen, D., Porter, D., 1996. The ungrateful dead. Planning 62(5):8-11. 
Schwab, J., 1997a. Vacating and replatting platted lands." Zoning News (May): 1-4. -., 1997b. The problem of antiquated subdivisions. Zoning News (April): 1-4. Schnidman, F., 1987. Resolving Platted Lands Problems: The Florida Experience. Land Assembly and Development: A Journal of Land Readjustment Studies. 1:2744.

Schnidman, F., Baker, R.L., 1985. Planning for Platted Lands: Land Use Remedies for Lot Sales Subdivisions. Monograph 85-2. Cambridge, Mass.: Lincoln Institute of Land Policy.

Selcraig, B., 1994. Albuquerque learns it really is a desert town. High Country News, Dec. 26, pp. $1-11$.

Sheng, Z. 2005. An aquifer storage and recovery system with reclaimed wastewater to preserve native groundwater resources in El Paso, Texas. Journal of Environmental Management 75(4):367-377.

Shultz, M.M., and Groy, J.B., 1998. The failure of subdivision control in the United States: A blueprint for local government action. Utah Law Review 1998(3): 569-674.

Sovocool K.A., Morgan, M., and D.Bennet. 2006. An in-depth investigation of xeriscaping as a water conservation measure. Journal of the American Water Works Association 98(2):82-93.

Stroud, H.B., 1983. Environmental problems associated with large recreational subdivisions. Professional Geographer 35(3), 303-313.

-., 1995. The Promise of Paradise: Recreational and Retirement Communities in the United States since 1950. Baltimore: Johns Hopkins University Press.

-., 2002. Coping with problems created by rapid growth and development at Cape Coral, Florida. The Florida Geographer 33:80-95.

Stroud, H.B., Spikowski, W.M., 1999. Planning in the wake of Florida land scams. Journal of Planning Education and Research 19:27-39.

Stroud, H.B., Tollefson, S., 2003. A vision for the future at Rio Rancho, New Mexico. The North American Geographer 5(1-2):129-141.

U. S. Water News Online, 1996. Wells which supply unmetered water hinder conservation efforts. http://www.uswaternews.com/archives/arcconserv/6wellcons.html.

Wolff, A. 1972. Invest in the West, New Yorkers fall for land con. New York Magazine 5:52-57.

-., 1973. Unreal Estate. San Francisco: Sierra Club. 